\title{
Comparison of two different methods for evaluating boar semen morphology
}

\author{
Comparación de dos diferentes metodologías de evaluación de la morfología \\ del semen porcino
}

\author{
G Oberlender*, LDS Murgas, MG Zangeronimo, AC Silva, LJ Pereira, RAL Muzzi \\ Department of Veterinary Medicine, Division of Physiology and Pharmacology, Federal University of Lavras, \\ Lavras, Minas Gerais, Brazil.
}

\begin{abstract}
RESUMEN
El objetivo de este estudio fue comparar el uso y la eficacia de dos técnicas para evaluación de la morfología espermática del semen porcino. La preparación húmeda con una solución de formaldehído-citrato 2,94\% y otra con el uso del colorante Rosa de Bengala. Se evaluaron 58 eyaculados de ocho verracos de alto desempeño, con edad entre 20 y 25 meses. Después de la recogida del semen, la morfología espermática fue evaluada por dos técnicas: la preparación húmeda convencional (solución de formaldehído-citrato 2,94\%) observada en microscopio de contraste de fase (1.000X de magnificación) y la técnica que utiliza un frotis preparado a partir del colorante Rosa de Bengala, analizado bajo un microscopio óptico (400X de magnificación). Se observó que el porcentaje de cambios de la cabeza, acrosoma, pieza intermedia y el total de cambios morfológicos no fueron diferentes $(\mathrm{P}>0,05)$ entre los dos métodos. Se obtuvo un mayor número de defectos de la cola $(\mathrm{P}<0,05)$ con el uso de la técnica de tinción con el colorante Rosa de Bengala en comparación con la técnica convencional. Esto se explica por el manejo en la preparación del frotis que puede conducir a una mayor probabilidad de romper la cola, lo que conduce a la visualización de la anomalía cola rota. Se puede concluir que el uso del colorante Rosa de Bengala es un método eficaz para la evaluación de la morfología del semen porcino, señalando que importantes cuidados deben ser tomados, especialmente en la preparación del frotis para que no ocurran cambios en los resultados, principalmente en los cambios de la cola.
\end{abstract}

Key words: formaldehyde-citrate, Bengal Rose, spermatic alterations, swine.

Palabras clave: alteraciones espermáticas, cerdos, formaldehído-citrato, Rosa de Bengala.

\section{INTRODUCTION}

Artificial insemination (AI) is a technique that has been developed rapidly worldwide, and is currently a reality for pig farms that employ technology (Acosta et al 2007, Vyt 2007). Therefore, various aspects that influence reproductive efficiency should be under control to prevent failures in the use of this biotechnology which can reverse the economic viability of the process as a whole. Among these aspects is the proportion of morphological changes observed in the fresh ejaculate.

The fresh semen evaluation is highly important because it reflects the seminal quality of the boars that are being used for roofing. This evaluation can be performed on both, the animals for natural mating and the ejaculate to be used for the preparation of AI doses in order to determine its quality. In the case of AI, since the ejaculate is divided into several doses, it is necessary to evaluate the quality of the insemination dose, because problems of infertility and subfertility may have a direct influence on increasing the return rate to estrus and/or decrease the rate of parturition.

Accepted: 05.04.2012.

* Caixa postal 3037, CEP 37.200-000, Brasil; guilherme_oberlender@ yahoo.com.br
Another important factor is the consequent reduction in litter size, generating a lower economic return for the producer (García-Ruvalcaba et al 1999).

It is important to identify sperm morphology due to its potential for fertilization and it also helps in the disposal of ejaculates and boars. It is known that certain changes, depending on location, have a negative impact on sperm movement and consequently on fertilization (Chenoweth 2005). Therefore, the evaluation of sperm morphology is essential in the pig production system. Nevertheless, this practice has often been discarded or has not received attention, giving more importance to evaluations of sperm motility and intensity of motion.

To study the sperm morphology in semen samples, multiple solutions and dyes are used in order to highlight the sperm cells. It should be noted that to carry out this analysis, different techniques and methodologies should be implemented using different techniques and methodologies to make the results more reliable. The fixation solutions commonly used are formaldehyde-saline solution (formaldehyde + sodium chloride) and/or formaldehyde-citrate (formaldehyde + sodium citrate). The most used dyes are Giemsa, Bengal Rose, Eosin-Negrosin, among others (Cardoso et al 2005). Comparisons of the use of dyes with the conventional wet preparation for the evaluation of sperm morphology in several species, such as sheeps, bovine and 
fish, have been reported by some authors (Streit-Junior et al 2004; Viu et al 2005; Silva et al 2008).

According to the above mentioned, the aim of this study was to compare the use and effectiveness of two different techniques for assessing sperm morphology, one being wet preparation with a formaldehyde-citrate solution $2.94 \%$ observed in phase contrast microscope and the other a smear with the Bengal Rose dye observed under an optical microscope.

\section{MATERIAL AND METHODS}

This study was conducted at the Department of Veterinary Medicine (DVM) of the Federal University of Lavras, during a period of three months. 58 ejaculates from eight high performance boars aged between 20 and 25 months were evaluated, they had been previously tested and considered suitable for reproduction. The animals were housed in individual pens located in a shed with concrete floor and tiled roof asbestos cement. They were fed 3.0 to $3.5 \mathrm{~kg}$ of feed per day and given water ad libitum through manual drinking fountains like a nipple.

The semen collections were performed using the gloved hand method, with the help of a fixed dummy. Each ejaculate was collected in a bottle/container graduate $(\mathrm{mm}-\mathrm{mL})$ with a capacity of $500 \mathrm{~mL}$, preheated to $37^{\circ} \mathrm{C}$ and protected by isothermal container (thermal cup of collection) according to the method described by Hancock and Howell (1959). After collection, the ejaculates were evaluated for the routine characteristics of seminal quality. The volume (measurements was performed through the graduate bottle/container), smell (presence of smell of urine, blood or other contaminations) and appearance of the ejaculate (watery, milky or milky serum) were evaluated macroscopically. The motility and intensity of motion, spermatic concentration (Neubauer chamber - $\mathrm{x}$ $10^{9} \mathrm{sperm} / \mathrm{mL}$ ), viability and morphology were microscopically evaluated.

To assess motility, three subsamples from each sample were placed on warm glass slides $\left(37^{\circ} \mathrm{C}\right)$. The slides were examined under a phase contrast microscope (400X). A total of 10 microscopic fields were assessed to determine the percentage of spermatozoa with rapid progressive motility and intensity of motion. Spermatic motility was expressed as a progressive motility percentage and the intensity was classified on a $0-5$ scale with 5 being the maximum intensity. The viability (live:dead ratio - \%) was calculated by counting the number of live cells (without color) and dead cells (pink) using optical microscopy (400X), after combining one drop of semen with one drop of eosin-negrosin.

Two techniques were used for the evaluation of sperm morphology, the evaluation through conventional wet preparation (formaldehyde-citrate solution $2.95 \%$ formaldehyde + sodium citrate) and the preparation of a smear using the Bengal Rose dye (3\% dye diluted in distilled water). For the wet preparation, about five drops of fresh semen from each ejaculate were added to $1.0 \mathrm{~mL}$ of citrate-formaldehyde solution $2.95 \%$ in a microtube (type Eppendorf). Then, approximately $10 \mu \mathrm{L}$ of this solution was placed between the slide and coverslip, and was observed in a phase contrast microscopy (1.000X magnification). The differential count of 100 spermatic cells was evaluated and the percentage of normal sperm and with abnormalities was calculated (Scheid 1993).

The evaluation of the morphology using the Bengal Rose dye was performed by preparing a smear from one drop of fresh semen and a drop of dye into the slide. The smear was performed by placing the tip of the upper blade on the lower blade (which has a drop of semen and dye) in an angle of $45^{\circ}$, and the upper blade slid smoothly down the length the lower blade. After preparation of the smear, it was dried at room temperature for a period of 10 minutes. Later, there was a differential count of 100 cells under an optical microscope (400X magnification) and the number of normal and abnormal sperm was determined in percentage. The percentages of head and tail anomalies, defects in acrosome and middle piece, the presence of proximal cytoplasmic droplet and the total alterations were evaluated in all 58 samples using both techniques.

The data were subjected to non-parametric analysis as the means of variables did not achieve normality, even after data transformation (square root option). The averages obtained were compared by Kruskal Wallis test when there was significance at chi-square test $(\mathrm{P}<0.05)$. All statistical analyzes were performed using the statistical package SPSS for Windows version 17.0 through a simple model to compare the means of the two treatments (technique for determining spermatic morphology) in different observed morphological changes.

\section{RESULTS AND DISCUSSION}

The values of the seminal parameters obtained for volume $(286.90 \pm 88.59 \mathrm{~mL})$, concentration $\left(0.256 \pm 0.082-\mathrm{x} 10^{9}\right.$ sptz/mL), motility $(83.97 \pm 6.87 \%)$, intensity of motion $(3.22 \pm 0.62-0-5)$ and viability $(90.19 \pm 6.32 \%)$, from the 58 ejaculates of eight boars were normal for swine species and they agree with the values of semen quality established by the Brazilian College of Animal Reproduction - CBRA 1992 for boars destined to AI programs (Fonseca et al 1992). The normal ejaculate volume of male pigs can vary from 50 to $500 \mathrm{~mL}$ with an average volume close to $200 \mathrm{~mL}$ (Corrêa et al 2001). According to the same author, boar semen should have the following fresh characteristics so that it can be used for processing doses and subsequent AI: sperm motility above $70 \%$ and spermatic intensity of motion at least 3.0 (on a scale from 0 to 5).

The sperm viability is an auxiliary test, carried out by a smear with the dye eosin-negrosin, in the evaluation of motility. According to Fonseca et al (1992) the values of viability always are higher than motility in approximately 
2 to $10 \%$. This occurs because the sperm with circular motions are not considered in the examination of sperm motility, however, since they are alive they are detected using the dye eosin-negrosin.

The values of the morphological changes observed from the use of both techniques are presented in table 1 . There was no difference $(\mathrm{P}>0.05)$ for the morphological alterations of head, acrosome, middle piece and total morphological changes evaluated in the two different methodologies. For tail alterations, a higher average $(\mathrm{P}<0.05)$ was obtained when using the smear with the Bengal Rose dye $(8.66 \pm 8.54 \%)$ compared with the conventional wet preparation - formaldehyde citrate solution $2.94 \%$ (5.45 $\pm 5.64 \%)$. For proximal cytoplasmic droplet alteration, an average of $3.50 \pm 5.44 \%$ was obtained in conventional wet preparation, a value that was higher $(\mathrm{P}<0.05)$ than the one found when using the smear technique with Bengal Rose dye $(0.86 \pm 1.57 \%)$.

Silva et al (2008) studied the functionality of the Bengal Rose dye compared to conventional wet preparation (saline formaldehyde solution) in the evaluation of spermatic morphology of sheeps semen and they did not find differences for defects of the head, middle piece and tail. Viu et al (2005) did not observe differences in the percentages of morphological changes of bovine semen in comparison to the wet preparation when using Panótico dye. In fish, Streit-Junior et al (2004) worked with different solutions and dyes to evaluate the sperm morphology of pacus (Piaractus mesopotamicus) semen and concluded that the use of Bengal Rose dye showed the best results for the evaluation of this parameter in this species.

In the present study, the smaller proximal cytoplasmic droplet changes when using the Rose Bengal dye were different to those observed by other authors who found no differences in this parameter (Viu et al 2005, Silva et al 2008). On the other hand, Villaverde et al (2008) also observed in cats a reduction of observation of these changes using the Rose Bengal dye compared to the Karras staining method. According to the authors, the processing of semen with Bengal Rose can lead to a detachment of the drops or even the staining, which does not achieve a good marking of these structures, leading to a reduced visualization of changes. Therefore, in the present study this may have been caused by the low penetration and ability of the dye to properly discriminate the changes of this structure.Further studies should be carried out to compare the efficacy of the Bengal Rose dye in boars semen to provide visualization of this change which has a great impact on the fertility of swine species.

Since there were no significant differences observed in alterations of head, acrosome, middle piece and total morphological changes, we can infer that the Bengal Rose dye is an efficient method for the detection of all these morphological changes in fresh boar semen. According to Zambelli and Cunto (2006) the use of Bengal Rose dye for the assessment of sperm morphology is very important, since it allows the differentiation of all sperm structures, especially the acrosome, with a low occurrence of artifacts. The low values of acrosome defects obtained in this study may be explained by the fact that high performance reproductive boars were used, with high quality seminal characteristics. In addition, the evaluated samples were fresh semen, not subjected to any processing such as dilution or freezing that could cause a higher percentage of defects in the structure. Moreover, the average for acrosome was within the range suggested by CBRA 1992, which proposes that fresh boar ejaculated should have at the most 5\% of changes in this structure (Fonseca et al 1992).

The increase in tail changes and the numerical difference observed for head changes $(0.40 \pm 0.86 \%)$ using the Bengal Rose dye can be explained by the preparation of the smear on the slide. It was observed that out of the total tail defects found, 65\% were tail broken and 53\% of total head changes were due to isolated head change $(0.21 \pm 0.74 \%)$. This occurs because at the time of smear preparation, the tip of a slide is in close contact with another slide, approximately 45 degrees. When one the slide is slipped on the other and this movement occurs in a very strong way, it can lead to the appearance of a large number of lesions in sperm, mainly observed in the tail and in the head (rupture or break) and therefore a higher number of broken tails and isolate head can be observed. Also, the tail changes observed when using this dye could be due to the possible osmotic stress that may occur when

Table 1. Mean values of sperm alterations in head, acrosome, middle piece, tail, proximal cytoplasmic droplet and total observed alterations from 58 ejaculates evaluated using two different methodos for assessing sperm morphology.

Valores medios de las alteraciones espermáticas de cabeza, acrosoma, pieza media, cola, gota citoplasmática proximal y total de alteraciones observadas en los 58 eyaculados evaluados a partir de dos diferentes metodologías de evaluación de la morfología espermática.

\begin{tabular}{lcccccc}
\hline \multirow{2}{*}{ Evaluation technique } & \multicolumn{5}{c}{ Analyzed variables $(\%)^{1}$} \\
\cline { 2 - 7 } & AHD & Acrosome & AMP* & ATL* & PCD* & Total \\
\hline Wet preparation & $0.24 \pm 0.57$ & $0.33 \pm 0.87$ & $0.22 \pm 0.59$ & $5.45 \pm 5.64 \mathrm{a}$ & $3.50 \pm 5.44 \mathrm{a}$ & $13.05 \pm 8.48$ \\
Bengal Rose dye & $0.40 \pm 0.86$ & $0.40 \pm 1.15$ & $0.24 \pm 0.47$ & $8.66 \pm 8.54 \mathrm{~b}$ & $0.86 \pm 1.57 \mathrm{~b}$ & $11.88 \pm 7.88$ \\
\hline
\end{tabular}

$1 \quad$ Means followed by different letters in columns differ by Kruskal Wallis $(\mathrm{P}<0.05)$.

* $\mathrm{AHD}=$ Alterations of head; AMP = Alterations of middle piece; $\mathrm{ATL}=$ Alterations of tail $\mathrm{PCD}=$ Proximal cytoplasmic droplet. 
Bengal Rose dye is diluted in distilled water and not in a isosmotic buffer (Weitze 1990). Despite this difference found between the two methods for the identification of changes in the tail and the head, the averages found were lower than those suggested by CBRA 1992, which propose that the pig ejaculated should have at most $10 \%$ of changes in tail (Fonseca et al 1992).

As reported by Silva et al (2008), it was found that both the conventional technique of sperm morphology evaluation and the use of Bengal Rose dye allowed to visualize the sperm cells structure with a high sharpness of the plasma membrane, facilitating the identification of morphological defects. A high resolution and definition of the sperm cell boundary was obtained through the staining technique, observinged an excellent quality of the blades made (figure 1). These findings, according to Silva et al (2008), were also reported by Rodrigues and Rodrigues (1998), Galvani et al (2000) and Streit-Junior et al (2004) who worked on canine frozen semen, Nelore bulls semen and pacus semen, respectively.

It can be concluded that the Bengal Rose dye is an efficient method for evaluating the sperm morphology of boar semen. Special care must be taken, especially when preparing the smear to avoid changes on the results, mainly changes in tail and head (broken or ruptured tail and isolated head).

The Bengal Rose dye offers great convenience in their preparation and application of the technique. The evaluation of sperm morphology can be performed using

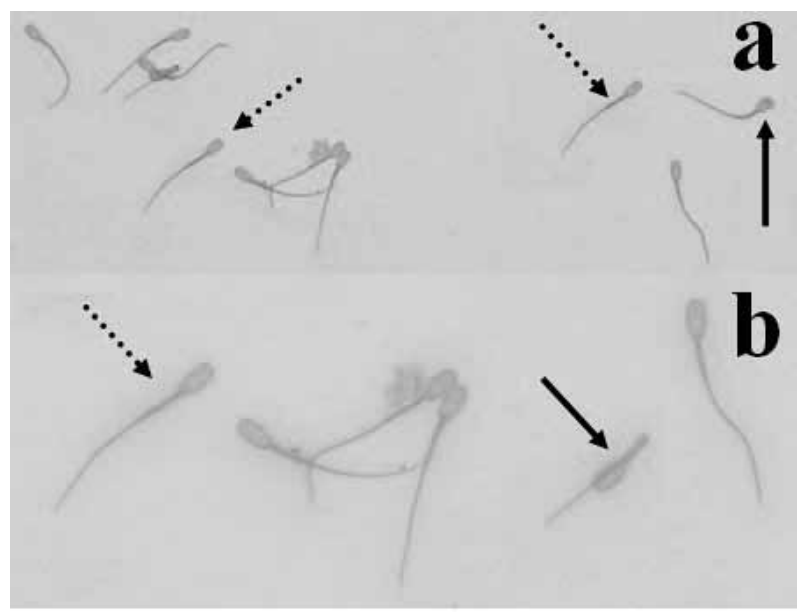

Figure 1. Boar sperm stained with Rose Bengal dye, being a) sperm showed normal morphology (hollow arrows) and sperm with ruptured acrosome (entire arrow) (200X magnification) and b) normal sperm (hollow arrow) and sperm coiled tail (entire arrow) (400X magnification).

Espermatozoides porcinos teñidos con el uso del colorante Rosa de Bengala, siendo a) espermatozoides con morfología normal (flechas punteadas) y espermatozoides con el acrosoma roto (flecha continua) (200X de magnificación) y b) espermatozoide normal (flecha punteada) y espermatozoide con la cola enrollada (flecha continua) (400X de magnificación). optical microscope and therefore the technique has a low cost, making it an important method to be used on the field, mainly because it allows the evaluation almost immediately after a semen collection from a boar. Further studies should be conducted to compare and evaluate the effectiveness of this staining technique in the evaluation of sperm morphology of boar semen, against other available methodos such as the Papanicolaou, Giemsa and eosinNigrosine staining.

\section{SUMMARY}

The objective of this study was to compare the use and effectiveness of two different techniques for assessing sperm morphology, the conventional wet preparation with a of formaldehyde-citrate solution $2.94 \%$ and the smear using Bengal Rose dye. 58 ejaculates from eight high performance boars aged between 8 and 25 months were evaluated. The sperm morphology was evaluated after collection of each ejaculate using two techniques: conventional wet preparation (formol citrate solution $2.94 \%$ ) observed in phase contrast microscopy (1.000X magnification) and a smear prepared with Bengal Rose dye, examined under an optical microscope (400X magnification). It was observed that the percentage of alterations of head, acrosome, middle piece and total morphological changes did not differ $(\mathrm{P}>0.05)$ between the two methods. A higher number of tail defects $(\mathrm{P}<0.05)$ was obtained by using the smear technique with Bengal Rose dye when compared to the conventional technique, this was probably due to the preparation technique of the smear that could result in a greater chance of tail breaking, leading to the visualization of this anomaly. It is concluded that the use of the Bengal Rose dye is an efficient method for evaluating the sperm morphology of boar semen, and thats pecial care should be taken when preparing the smear to avoid affecting the results, mainly regarding tail alterations.

\section{ACKNOWLEDGEMENTS}

This study was supported by FAPEMIG (Research Support Foundation of the State of Minas Gerais), CNPq (National Council for Scientific and Technological Development), CAPES (Coordination of Improvement of Higher Education Personnel), Veterinary Medicine and Animal Science Graduate Program and Graduate Directory of the Federal University of Lavras, Brazil.

\section{REFERENCES}

Acosta MJ, M Rueda, R Perdigón. 2007. Comparación de dos técnicas en la determinación de morfoanomalías del semen porcino. Rev Unell Cienc Tec 25, 32-39.

Cardoso RCS, AR Silva, LDM Silva. 2005. Métodos de avaliação do sêmen canino congelado. Rev Bras Reprod Anim 29, 179-187.

Chenoweth PJ. 2005. Genetic sperm defects. Theriogenology 64, 457-468.

Corrêa MN, W Meincke, T Lucia Jr., JC Deschamps. 2001. Processamento do sêmen. In: Corrêa MN, Meincke W, Lucia Jr. T, Deschamps JC (eds). Inseminação Artificial em Suínos. Editora PRINTPAR, Paraná, Brasil, Pp 85-122.

Fonseca VO, VR Vale Filho, A Mies Filho, JJ Abreu. 1992. Espermiograma. In: Fonseca VO, Vale Filho VR, Mies Filho A, Abreu JJ (eds). Procedimentos para Exame Andrológico e Avaliação de Sêmen Animal. Editora CBRA, Belo Horizonte, Brasil, Pp 6-30.

Galvani F, EP Costa, CAA Torres, JH Bruschi, MD Santos, RW Pinheiro. 2000. Perímetro escrotal, características físicas do sêmen e morfopatológicas dos espermatozóides de touros Nelore de alta libido comparados com animais de libidos inferiores. Ars Veterinária 16, 97-103. 
García-Ruvalcaba JÁ, S Lapuentes, D Corcuera. 1999. Avaliação prática do sêmen. Suinocultura Industrial 21, 32-35.

Hancock JL, GJR Howell. 1959. The collection of boar semen. Vet Rec 71, 664-665.

Rodrigues BA, JL Rodrigues. 1998. Efeito da adição de diferentes concentrações de albumina sérica bovina (BSA) ao diluidor à base de tris sobre a viabilidade in vitro do sêmen canino criopreservado. Arquivo da Faculdade de Veterinária da UFRGS 26, 32-49.

Silva LM, CMG Silva, TV Cavalcante, JL Ferreira, JAT Souza. 2008. Utilização do corante Rosa Bengala no método de preparação úmida para avaliação morfológica de sêmen ovino. Rev Cient Prod Anim $10,174-180$.

Streit-Junior DP, GV Moraes, RP Ribeiro, JÁ Povh, ED Souza, CAL Oliveira. 2004. Avaliação de diferentes técnicas para coloração de sêmen de peixes. Arq Ciênc Vet Zool 7, 157-162.
Villaverde AISB, CM Melo, JE Corrente, FO Papa, MD Lopes. 2008 Comparação entre dois métodos de coloração para análise morfológica e acrossomal de espermatozóides de gato doméstico (Felis catus). Ciênc Anim Bras 9, 686-692.

Viu MAO, AFM Viu, RE Rabelo, AF Romani, Ferraz HT, Santos RE. 2005. Emprego de corante panótico na preparação de câmara úmida para avaliação da morfologia espermática em bovinos. Resumo do XVI Congresso Brasileiro de Reprodução Animal, Goiânia, Goiás, Brasil.

Vyt P. 2007. Examination and storage of liquid pig semen. Doctoral Thesis, Faculty of Veterinary Medicine, Ghent University, Ghent, Belgium.

Weitze K. 1990. The use of long-term extenders in pig AI - a view of the international situation. Pig News and Information 11, 23-26.

Zambelli D, M Cunto. 2006. Semen collection in cats: techniques and analysis. Theriogenology 15, 159-165. 